\title{
Trends and developments in historical pragmatics
}

Taavitsainen, Irma ; Jucker, Andreas H

Other titles: Introduction to : Historical pragmatics

Posted at the Zurich Open Repository and Archive, University of Zurich ZORA URL: https://doi.org/10.5167/uzh-38864

Book Section

Published Version

Originally published at:

Taavitsainen, Irma; Jucker, Andreas H (2010). Trends and developments in historical pragmatics. In: Jucker, Andreas H; Taavitsainen, Irma. Historical pragmatics. Berlin / New York: De Gruyter Mouton, 3-30. 


\title{
1. Trends and developments in historical pragmatics
}

\author{
Irma Taavitsainen and Andreas H. Jucker
}

\section{The aim of the handbook}

The aim of the Handbook of Historical Pragmatics is to provide an up-to-date, comprehensive account of research in the field, but an additional and most ambitious goal is to go beyond that by defining the approach in more detail than has been done before, showing the relationships between pragmatic studies and other related enquiries. This contextualising work is initiated in this introduction by way of a summary; individual chapters probe more deeply into their special areas of interest. We hope that both current and future scholars of various aspects of historical pragmatics will benefit from discussion of the place of individual topics in the broader context of the field. The volume will also provide an exploration of the place of historical pragmatics both within the field of pragmatics and within the field of historical linguistics, and it will provide a roadmap for interdisciplinary cooperation between historical pragmatics and neighbouring fields.

In this introduction, we would like to draw attention to some recent paradigm shifts in linguistics that have been crucial for the development of historical pragmatics (section 2). We provide an initial outline of historical pragmatics by discussing various definitions of the field in an attempt to define the scope of the approach and highlight some of its pertinent features (section 3 ). We briefly discuss some data problems (section 4) and elaborate on the defining features of the field, viz. the study of language use in earlier periods, the diachronic development of language use and the communicative causes of language change (section 5). Section 6 is devoted to a range of fundamental problems in historical pragmatics, such as the meaning problem, i.e. the problem of establishing not only the sentence meaning in historical data but appropriate speaker meanings. Finally, we will briefly contextualise the 21 contributions that appear in this volume (section 7).

\section{Paradigm shifts in linguistics}

The ultimate decades of the twentieth century saw several important and fundamental paradigm shifts in linguistics. In the words of Traugott (2008: 207), "what was marginal in the 1970 s has come to be of central interest, above all pragmatics". As a result, phonology, morphology, syntax and semantics are no longer privileged fields of linguistics; the study of language use is considered to be just as important, or perhaps even more important in the sense that a proper study of language struc- 
tures must take into consideration how these structures are actually used and interpreted. Further shifts concern the move from homogeneity to heterogeneity. Variationist studies have become a major trend. Language is seen as diachronic, social and dynamic and not as just a synchronic and static system. "It is now almost a truism that virtually no speaker has just one homogeneous system; there are different knowledge structures in different domains (work, family, religion), and no domain proves a complete range of communicative power" (Traugott 2008: 208). Traugott lists several further shifts, such as the shift from introspective data to empirical data of all kinds; the shift from decontextualised to contextualised sentences; and the related shift from the study of the decontextualised language product (i.e. text) to interactional processes. All these aspects are prominent defining features in historical pragmatics: we rely on empirical data in context and focus on the joint negotiation of meaning. The inception of historical pragmatics in the 1990s owes a great deal to the above-mentioned paradigm shifts. In the course of 15 years, the position of historical pragmatics within pragmatics has changed from marginal to central, and the sheer number of publications in the field has grown so much that a dedicated handbook is in order.

Jucker's (1995) book on historical pragmatics was an early collection of relevant studies in the field. It introduced the distinction between pragmaphilology and diachronic pragmatics with form-to-function and function-to-form mapping, which is frequently quoted in the literature. In the wake of the 1995 volume, conferences on the topic, plus panels at larger conferences were organised. In the year 2000, the new Journal of Historical Pragmatics gave the field an acknowledged place within the research paradigm. Textbooks of pragmatics and of historical linguistics, handbooks and encyclopaedias have increasingly started to devote a separate chapter or even several chapters to historical pragmatics (see, for instance, Brinton 2001, 2006; Traugott 2004, 2006; Held 2006; Radtke 2006; Seoane 2006; Jucker 2006, 2008; Culpeper 2010; Taavitsainen forthcoming). And, in 2007, the volume edited by Fitzmaurice and Taavitsainen (2007) provided a more critical assessment of the key questions and the convergence of different traditions of reading and analysing discourse from the perspective of historical pragmatics. The growing maturity of the field can be verified in the versatility of the approaches and methods and in its broadening scope: history is not only something of the past, but includes the present and the future (Taavitsainen and Fitzmaurice 2007: 29).

\section{Definitions and scope}

The field of pragmatics in general has always been split into two more or less distinct approaches. On the one hand, there is a fairly narrow conception of pragmatics that deals with information structure, implicit meanings and cognitive aspects of utterance interpretation, and, on the other hand, there is a wider conception 
of pragmatics that also includes the social context of language use. The narrow view, also called the component view, is more typical for Anglo-American scholars, while the wider approach to language use, the perspective view, which also includes social aspects, is more typical for Continental European pragmaticists (see Huang 2007: 4-5; Jucker 2008: 894-895).

The distinction is clearly reflected in the relevant textbooks and handbooks. The Handbook of Pragmatics edited by Horn and Ward (2004), for instance, explicitly excludes the broader sociologically-based European view of pragmatics and concentrates its coverage on the "more narrowly circumscribed, mainly Anglo-American conception of linguistic and philosophical pragmatics and its applications" (Horn and Ward 2004: xi). Huang (2007: 5), too, adopts the AngloAmerican perspective by focusing on "topics emerging from the traditional concerns of analytical philosophy". Verschueren (1999: 7), on the other hand, defines pragmatics as "a general cognitive, social, and cultural perspective on linguistic phenomena in relation to their usage in forms of behaviour". The Handbook of Pragmatics edited by Verschueren et al. (2003) also casts a wider net and includes topics that approach the study of the use of language from a social or cultural perspective. It is this Continental European perspective of pragmatics that has been adopted both for the current handbook and for the entire series in which it appears (see Preface to Handbook Series).

This distinction between the mainly Anglo-American and the mainly European conceptions of pragmatics has had an impact on historical pragmatics, even though the boundaries are less clear-cut for historical pragmatics than for pragmatics in general. As a representative of the Anglo-American tradition, Traugott, for instance, defines historical pragmatics as "usage-based approach to language change" (2004: 538). For her, pragmatics deals with "non-literal meaning that arises in language use" (2004: 539), though in her 2008 article she seems to move towards the broader concept (see above). Much of the work within this tradition has been devoted to the grammaticalisation of linguistic elements, to pathways of change and to the study of the function of different conversational maxims in language change (see e.g. Traugott and Dasher 2005; Brinton 2006).

The wider European tradition, on the other hand, takes a sociologically-based approach and wants to understand the patterns of human interaction within their social conditions of earlier periods (see, for instance, Held 2006; Jucker 2006, 2008; Taavitsainen forthcoming), and there is a considerable overlap with sociolinguistics. It also wants to understand the developments of these patterns and the principles that govern them. In some cases, the focus is provided by the element under analysis as in the case of address terms, speech acts or dialogue analysis, but language is also seen as situated within discourse domains; therefore, language use in religious discourse, scientific discourse, media discourse, courtroom discourse and personal correspondence has been studied in detail in this volume. 
Taavitsainen and Fitzmaurice (2007: 13), representatives of the wider European tradition, make an attempt to reconcile the views and define historical pragmatics as follows: "Historical pragmatics focuses on language use in past contexts and examines how meaning is made. It is an empirical branch of linguistic study, with focus on authentic language use of the past". Jucker (2008), also a representative of the European tradition, defines historical pragmatics as follows:

In a broader sense adopting the more European conceptualization of pragmatics, historical pragmatics can be defined as a field of study that wants to understand the patterns of intentional human interaction (as determined by the conditions of society) of earlier periods, the historical developments of these patterns, and the general principles underlying such developments. (Jucker 2008: 895)

This definition includes the three areas of historical pragmatics mentioned above: the language use in earlier periods, the development of language use and the principles of such developments. It explicitly includes the societal conditions of human interaction. Language is studied within a larger communicative and social context. It is thus broader and more encompassing than e.g. Horn and Ward's conceptualisation of historical pragmatics.

Such definitions, while they may be important to delimit the contributions to a handbook such as the present one, do not constrain the work that is being done. Other publication outlets, such as the Journal of Historical Pragmatics, do not impose strict boundaries but invite contributions from neighbouring areas, such as sociohistorical linguistics or historical semantics as well. The borders are fuzzy and the neighbouring areas are overlapping, providing incentives for new lines of study, e.g. with new resources such as the Historical Thesaurus (see below).

In addition to the term "historical pragmatics", the term "historical discourse analysis" is sometimes used. Brinton (2001) points out that it is not easy to distinguish the fields of pragmatics and discourse analysis, but in her outline of historical discourse analysis she puts the emphasis "on the more formal aspects of text structure, such as discourse markers or grounding, rather than on the more notional elements of text semantics, such as presupposition or conversational maxims or on aspects of language use" (Brinton 2001: 139). In a recent encyclopaedia article, Culpeper (2010: 189) discusses the relation between the two terms "historical pragmatics" and "historical discourse analysis" and points out that the terminology is not constant yet, but that in the narrow Anglo-American conception of historical pragmatics, the term "historical discourse analysis" is sometimes invoked for what in the wider European conception is covered by the field of "historical pragmatics" itself.

"Historical dialogue analysis" is another frequently used label (e.g. Fritz 1994, 1995, 1997; Jucker, Fritz and Lebsanft 1999a). Fritz (1997: 47) argues that dialogue analysis is a central field within pragmatics and that, therefore, historical dialogue analysis should be at the centre of historical pragmatics. He envisages three 
basic concerns for historical dialogue analysis. First, historical dialogue analysis studies individual historical texts focusing on their pragmatic structures and the dialogues contained in them. Second, it compares earlier dialogue forms with later ones. As an example, he mentions a comparison of sixteenth-century forms of swearing in Switzerland with present-day practices (Lötscher 1981). And third, historical dialogue analysis studies the evolution of dialogue forms. Such an endeavour takes it for granted that different forms of dialogue exist and can be described. The analysis of the forms focuses on their organisation, their development and the degrees to which they are conventionalised and standardised.

\section{Data problems}

Historical pragmatics has to rely on written data, while pragmatics in general largely takes it for granted that the object of investigation should be naturally occurring spoken data. The same discrepancy is embedded in sociolinguistics and historical linguistics:

Historical pragmatics and, in a wider sense, historical sociolinguistics need access to spoken texts, preferably items of spontaneously spoken language of earlier periods; these are, however, no longer available. This plight has recently been referred to as the problem of "bad data". (Fries 1998: 85)

The "bad data problem" was formulated by Labov (1994: 11) as an inherent quality of periods without authentic records of spoken language: "Historical linguistics can then be thought of as the art of making the best use of bad data". His statement is echoed in several studies of the 1990s, and the data problems have been discussed widely and different solutions have been proposed (Jacobs and Jucker 1995: 6-10; Culpeper and Kytö 2000; Jucker 2000a, 2008: 895-897; Nevalainen and Raumolin-Brunberg 2003: 26-28; Taavitsainen and Fitzmaurice 2007: 18-21). Two approaches can be discerned: first, the search for material that is as authentic as possible; and second, the contention that even written language has a communicative purpose and therefore deserves to be studied from a pragmatic perspective. Koch and Oesterreicher (1985) have made these two approaches compatible with each other. In the following sections, we will briefly look at these two approaches and at Koch and Oesterreicher's proposal that replaces the dichotomy of written and spoken language with a scale from the language of immediacy to the language of distance that interacts with the dichotomy of the phonic and the graphic code. In the final part of this section, we will briefly discuss more recent developments in the requirements for authenticity and how these are related to recent technological developments in the availability of relevant data. 


\subsection{The search for authentic language}

For researchers who see written language as an imperfect rendering of actual, spontaneous spoken language use, it is important to search for instances of written language that are as close as possible to the "real thing". Historical (written) texts often contain accounts of spoken language, and Rissanen (1986: 98), for instance, argued that features that are consistently more frequent in written representations of spoken language than in other types of written language may safely be assumed to be even more frequent in the spoken language of that period. Particularly promising genres in this respect are court records, which provide accounts of the spoken proceedings in court (see Doty, this volume). Drama texts and other fictional texts have also been used as a substitute for the spoken language of the past. Fictional texts obviously deviate to some extent from the actual spontaneous language usage, but the use of such material has regularly been justified on the grounds that it is the only possible source for the spoken language of the past (Salmon 1965: 105), and that "there is nothing else" (Brown and Gilman 1989: 170). More positive views are that drama comedies provide materials for studying features that primarily belong to spoken language, such as interjections, and that, of the genres included in the Helsinki Corpus, drama comedies provide "the nearest approximation to everyday spoken language in historical texts" (Taavitsainen 1995: 460). Mazzon, in a paper on address terms in the plays by Shakespeare, argued explicitly that "theatrical works mimic spoken interaction relatively more faithfully than other types of literary works" (Mazzon 2003: 223; see also Fitzmaurice, this volume).

The Corpus of English Dialogues compiled by Culpeper and Kytö is based on the assumption that data for historical pragmatic investigation should be based on speech-related material (see Culpeper and Kytö 1999, 2000, 2006, 2010). The corpus contains material from four kinds of text that are all - in one way or another closely related to spoken language: comedy drama, prose fiction, trial proceedings and witness depositions. The material covers the period from 1600 to 1720 . The corpus is intended to allow a comparison between what might be called "recorded speech" in trial proceedings and witness depositions, and constructed, imaginary speech in comedy drama and prose fiction. In the introductory chapter to a recent book based on the corpus, they discuss the data problem of speech-related texts (Culpeper and Kytö 2010).

Authentic communicative and dialogic language use has also been preserved in the form of personal letters, and indeed this form of interaction in historical periods has received a large amount of scholarly attention (see Palander-Collin, this volume). There are, however, problems connected with the data, as many of the letters are edited for various purposes, with modern conventions and normalisations to varying degrees imposed upon the original texts (see below). 


\subsection{The communicative nature of written language}

In addition to the approaches that focus on types of data that are hypothesised to be close to spoken language or data that is by its very nature dialogic and communicative, such as letters, many researchers in historical pragmatics have devoted their attention to the communicative impact of written language per se. News discourse, for instance, has been extensively analysed from pragmatic perspectives without hypothesising any close connection to spoken language. Early Modern English pamphlets, for example, have been analysed as a form of early mass media (see Claridge, this volume). Pamphlets were printed, but they were often used in controversies and thus had a dialogic nature. They often had titles that alluded to their dialogic nature by including phrases such as "an answer to", "a reply to" or "a replication to the rejoinder" (Fritz, this volume).

Literary texts can also be studied as communicative acts as is highlighted by Sell (1991, 2000, 2001), who proposes a perspective on literature that focuses on the interaction of the real author with a real audience.

Literary writing and reading are viewed as uses of language which amount to interpersonal activity, and which are thereby capable of bringing about a change in the status quo. This means that my references to communicative pragmatics will carry a strong echo of the Greek root pragma (= "deed"). (Sell 2000: 2)

Sell views the writer and the reader as being engaged in a triangular situation in which they are in communication about some third entity. His view puts literature within the remit of a general theory of communication and makes it possible to talk about the politeness of an author, e.g. Geoffrey Chaucer, towards his readers (Sell 1985; see also Fitzmaurice, this volume).

\subsection{A model for studying spoken and written texts}

Koch and Oesterreicher (1985; see also Koch 1999) proposed a new way of looking at different types of language. They reconstruct the dichotomy of spoken versus written into a dichotomy based on medial realisation and a scale of communicative distance. A communicative act is realised either in the phonic medium or in the graphic medium. The scale of communicative distance describes whether the participants share a common physical context, whether the interaction takes place in a private or a public context, whether the participants are familiar with each other or not, and so on. Texts in the phonic medium typically display many features of communicative immediacy. A chat during a coffee break, for instance, takes place in a face-to-face situation, the communicators know each other, the context is more private than public, topics are allowed to develop freely and the partners talk spontaneously and generally cooperate in their communication. But there are also less typical instances of phonically realised texts, such as a funeral oration, which takes place in a public context in which some of the participants may know each 
other less well. The topic is prescribed, and the text is mostly monologic rather than dialogic.

Graphically realised texts, on the other hand, more typically display features of communicative distance. For typical forms of graphically realised texts, such as legal contracts, scientific treatises or newspaper articles, participants do not share a common physical context. The writers often do not know the readers of their text. The text is monologic and possibly rather formal, and it does not allow for spontaneity of the participants. But other graphically realised texts, such as email messages, Internet chat or short text messages may display many more signs of communicative immediacy.

In such a conception, the historical pragmaticist, while restricted to texts in the graphic medium, is not restricted to texts of communicative distance. He or she can use the whole spectrum of texts from communicative immediate to communicative distant ones. The model allows the analyst to be very precise about the features of communicative immediacy and the features of communicative distance, and the rather crude dichotomy between spoken and written language can be refined.

Court records, for instance, consist of a complex mixture of language that can be placed at different positions on the scale of communicative distance, even though all of it appears in the graphic code (Koch 1999: 410-412). The frame of the text consists of the legal modalities recorded by the court clerk for a future reader. This part is characterised by communicative distance. Embedded within the legal modalities, the clerk reports the interaction between the interactants present in the court: the judge, the defendant, lawyers and witnesses. Such language will be less distant than the legal formalities, but the courtroom imposes a fair degree of formality on the interactants, for some of whom the whole situation may be very unfamiliar and perhaps even threatening. Thus, it cannot be expected that this type of language reflects the language of immediacy. Within the proceedings in the courtroom, what has been said outside the courtroom may often become important, and it may be important for the case to have very accurate renderings of such utterances, e.g. in cases of slander, etc. It seems reasonable to assume that court clerks will have been particularly meticulous in recording the precise details of such instances of language use, and these instances are also likely to be characterised by the language of immediacy.

4.4. New requirements on authenticity and recent technological developments

Modern technology has brought us to a new phase where the old problems of authenticity versus making texts more readily available to modern scholars can be resolved without compromising scholarly requirements. For example, the editing of texts of past periods is entering a new phase with electronic editions. Texts can be presented in a multilayered frame with digital images of the original texts accompanied by diplomatic transcriptions and edited versions with annotations and ex- 
planatory notes, making medieval texts available to modern readers in a different way from earlier times (see Honkapohja, Kaislaniemi and Marttila 2009; Kytö, this volume). Scholarly libraries are changing their policies of access to their materials, e.g. Catalan scientific manuscripts in Austrian libraries are available to the public in high-quality images on the Internet. A large number of Early Modern English printed books have been digitised and can be accessed online (Early English Books Online, EEBO); eighteenth-century English books are also available (Eighteenth Century Collections Online, ECCO). These new resources are bound to enrich studies of these periods on several fronts, including book history, book illustration and reading history. Such studies can also enrich the scope of historical pragmatics and open up new possibilities for probing deeper into characteristics of the audiences and the reception of historical works.

New electronic resources are likely to change the research paradigms in historical pragmatics in the future. In the neighbouring area of historical semantics, the Historical Thesaurus of English (HTE), the result of 45 years of work, was recently released in book form; in the future an electronic version, compatible with the Oxford English Dictionary Online, will be available. The thesaurus relies on Oxford English Dictionary materials and organises them in a chronological order according to semantic fields to show what was available to speakers of English at any one point in the dictionary's long history, and how meaning potentials developed and changed. This resource will provide an asset for historical pragmatics studies that focus on language use in context. English historical corpora offer large electronic databases of material ready to be searched so that the studied items can be located for contextual analysis. We can expect a boost in empirical studies along these lines in the future.

\section{Language use, development and communicative causes}

In the definition and delimitation of the field of historical pragmatics, we mentioned three particular concerns that define the scope of historical pragmatics: the study of intentional language use within a social and cultural context in earlier periods of time, the study of the development of language use and the study of the communicative causes of language change in general. These concerns figure prominently in the various attempts to structure the field (Jacobs and Jucker 1995; Brinton 2001; Jucker 2008; Culpeper 2010). In the following, we want to elaborate these three concerns and mention some of the recent research that has added to our understanding of them. 


\subsection{Language use in earlier periods}

The pragmatic study of the use of language in earlier periods has been termed "pragmaphilology" by Jacobs and Jucker (1995: 11). According to them, pragmaphilology "describes the contextual aspects of historical texts, including the addressers and addressees, their social and personal relationship, the physical and social setting of text production and text reception, and the goal(s) of the text" (Jacobs and Jucker 1995: 11). Brinton, who uses the term "historical discourse analysis proper" for this field, describes it as "an application of discourse analysis to language history. It is the study of discourse forms, function, or structures - that is, whatever is encompassed by discourse analysis [...] - in earlier periods of a language" (Brinton 2001: 139). Such studies usually rely on a careful consideration of the social and cultural context in which language is used, and the further removed the period under scrutiny is from our own, the more difficult it is to develop an accurate picture. What looks familiar might have had different meanings, and the language cannot be understood without specialised training and instruction. With the increased linguistic distance, cultural distance also increases, e.g. the Anglo-Saxon world is very different from our own and motivations guiding communicators may differ in unpredictable ways.

These problems are exacerbated by the fact that studies that concentrate on the language of specific periods in the history of English or of other languages are often based on fictional materials, such as poems, narratives or plays. These fictional texts often depict worlds that are independent of the world in which they were written in the sense that they depict historical scenes, scenes that take place in countries that were foreign to the author or even entirely fantastic fairy-tale worlds. A substantial amount of work in historical pragmatics has been devoted to the works of the Middle English author Geoffrey Chaucer and to the plays written by William Shakespeare. It is for this reason that separate chapters in this handbook are devoted to these two authors (see Pakkala-Weckström on Chaucer, and Beatrix Busse and Ulrich Busse on Shakespeare).

A second area of historical pragmatic research that focuses on language use in specific historical periods is devoted to courtroom language. In particular, the language of the Early Modern English courtroom has been studied extensively. The interactions in Early Modern courtrooms differ considerably from present-day courtrooms in their basic assumptions. The modern principle that defendants are innocent until proven guilty was not in force; in fact, proceedings were based on an assumption that the defendant was guilty unless proven innocent. This had farreaching consequences not just for the fate of the defendants but also for the linguistic strategies chosen by the interactants in the courtroom. As in the case of fiction, the researcher has to analyse the linguistic strategies in several layers of context. The utterances are not just contextualised within, for instance, an Early Modern English courtroom, but they also have to be seen in the context of how 
court records were taken down in shorthand, written out in longhand or printed, of who the intended readers were and so on (see Doty, this volume, for an overview of research in this area).

\subsection{Diachronic development of language use}

The next approach goes one step further as it combines synchronic descriptions of language use into a diachronic view, ultimately studying language as a process of continuous development. This is, then, not only historical pragmatics but, to use Jacobs and Jucker's term, "diachronic pragmatics" in a more narrow sense (1995: 13). Brinton describes this approach as "less well developed than the other" and calls it "diachronic(ally oriented) discourse analysis" (2001: 140). "It involves a study of the changes in discourse marking, function, and structures over time. That is, discourse structure is treated on a par with phonological, morphological, syntactic and semantic structure as something which changes and develops over time" (Brinton 2001: 140). Brinton's description may have been true at the turn of the century, but the last few years have seen a proliferation of work in this area.

Jacobs and Jucker (1995) proposed a further distinction of this type of study into diachronic form-to-function mapping and diachronic function-to-form mapping. Diachronic form-to-function mapping takes a particular linguistic form, such as a specific discourse marker or an address term, as a starting point and traces its diachronic development. Brinton (1996, 1998, 2006), for instance, investigates the history of a broad range of discourse markers, or pragmatic markers as she calls them, such as gan, anon, hwat or only. In a more recent study, she analyses the origin and development of comment clauses, such as I daresy, (as) I say, I mean, or as/so you see in the history of English and argues that they do not derive from earlier matrix clauses but have a variety of origins, such as imperatives, adverbial adjuncts or relative clauses (Brinton 2008). In all these cases, the linguistic form (with spelling variations) is the starting point. The focus is on the early functions of these forms and how, in the course of time, these functions changed. Similar studies have been carried out on address terms. Brown and Gilman (1960) provide a model of diachronic analysis that is claimed to be applicable to all European languages that make a distinction between two pronouns of address for single individuals. Nevalainen and Raumolin-Brunberg (1995) trace the development of address terms in a corpus of Early English correspondence. The volume edited by Taavitsainen and Jucker (2003) contains several contributions dealing with the Middle English and Early Modern English address term systems, but it also includes e.g. chapters discussing respect in the history of German pronouns of address, and Czech address forms until 1700.

In diachronic function-to-form mapping, on the other hand, speech functions are taken as the starting point for the investigation and their different realisations across time are analysed. Speech acts with their functional definitions are an ob- 
vious case in point. Arnovick (1999), for instance, traces several speech acts in the history of English. The agonistic insult in English is one of her case studies, which she traces from the flyting of the Anglo-Saxon warrior to the competitive sounding of African-American youths. These speech acts, or speech events, as she calls them, are only comparable to the extent that they share a similar function, which in this particular case - could be described as verbal duelling. A history of compliments (see Taavitsainen and Jucker 2008) likewise relies on the comparability of the speech function of paying a compliment, and a history of apologies (Jucker and Taavitsainen 2008a) requires a continuing history of a speech act that is sufficiently identifiable as apology over the course of time.

However, in such histories we always have to expect both the form and the function to change to a certain extent even if - for analytical purposes - we take one or the other as a starting point (see also Culpeper 2010: 192). Arnovick's (1999: 95-118) account of the development of the leave-taking expression goodbye from God be with you provides a particularly telling example. In Early Modern English, God be with you entailed an explicit blessing and an implicit parting. The phrase developed into good-bye and in the process lost the element of blessing in its meaning.

\subsection{Communicative causes of language change}

The third approach was termed "discourse-oriented historical linguistics" by Brinton (2001: 140). In her words, "it is the study of 'discourse-pragmatic factors' in language change or of the discourse motivations behind diachronic changes, whether phonological, morphological, syntactic, or semantic" (Brinton 2001: 140).

Traugott and Dasher (2005), for instance, developed a far-reaching model that tries to adduce pragmatic motivations for semantic change and combine them with neo-Gricean pragmatics and ideas from cognitive linguistics and construction grammar. Linguistic expressions change their meaning over time because speakers use them to communicate and negotiate meanings in their interactions with each other. Meanings are conventionalised within speech communities but they are also constantly negotiated and re-negotiated in each interaction. Ad-hoc meanings that are repeatedly invoked may then become conventionalised for the entire speech community, that is to say the speaker may invite the addressee to draw specific inferences, and such "invited inferences" may then become conventionalised into new meanings. The English discourse marker in fact, for instance, derives from the Early Modern English lexeme fact meaning 'deed, action'. In certain contexts, the phrase invited the inference of the evidential meaning 'in practice/reality/actuality'. In such contexts, the proposition introduced by in fact was often understood in opposition to some other proposition and therefore regularly invited the inference of adversativity. And, finally, in fact functions at the discourse level to express the speaker's attitude towards the proposition (Traugott and Dasher 2005: 165-169). 
Thus the reasons for language change are located squarely in the communicative needs of the speakers and in their interaction with each other. The traditional distinction between language internal and language external causes of language change becomes ultimately blurred: language changes as a result of the changing communicative needs of speakers, but these communicative needs change as a result of the wider cultural and social developments of the language community. Thus both internal and external motivations count. Political events, social, spiritual and economic developments all have a bearing on the communicative needs of speakers, and as a result the language adapts to these changing needs. And, in an even more obvious way, technical innovations change the world and ways of communicating. The developing means of distance communication - from the early postal services to the telephone, telegraph, mobile phone and the Internet - have a direct bearing on communicative patterns.

\section{The problems of historical pragmatics}

Historical pragmatics deals with both larger and more elusive categories than traditional branches of historical linguistics, and its status on the map of historical linguistics is not as long-standing or established as that of historical phonology, for example. The regularities of sound changes are fairly well understood. Historical morphology and syntax have been studied extensively, as has semantics, which has also received attention within e.g. lexical studies, but changes at the pragmatic level are in many ways more difficult to trace. The reasons are manifold. In the following sections, we want to outline some of the main problems that are either unique to the investigation of pragmatic change or pose even greater challenges than at other levels of linguistic description.

Modes of linguistic change and the problems of historical pragmatics are embedded in the problems of language change in general, and various models have been proposed. Corpus methods in historical linguistics, for instance, are based on the view of language as a constantly changing entity with variation (e.g. Milroy 1992: 1). The variationist paradigm of language change was first articulated in the seminal article by Weinreich, Labov and Herzog (1968), where they introduced the idea of "orderly heterogeneity" with the changing paradigms in the proportions of linguistic variants indicating ongoing changes. The model has received a great deal of attention and inspired studies of phonological, morphological and syntactic change. The variationist paradigm seems to be applicable beyond the well-established areas, e.g. Nerlich (this volume) discusses metaphorisation and metonymisation as strategies of meaning-making processes through multiple meanings to new meanings. The variationist view is applicable to the description of pragmatic utterances, as there are alternative ways of expressing the same meanings, and speech acts, for instance, can be performed in multiple ways (see Jucker and Taavitsainen 
forthc.). But, in general, our present methods are mostly either corpus aided or qualitative, and attempts at more quantitative approaches are few (e.g. Jucker et al. 2008; Valkonen 2008). It is difficult to find empirical evidence of change in proportions of occurrence of pragmatic phenomena, though in some cases it is possible to establish more general diachronic lines of development (see below).

\subsection{Pathways-of-change problem}

Many studies in historical linguistics have tried to generalise trends across large numbers of individual changes that are observable in a diachronic analysis. Is it possible to find pathways of change that are common to all these changes or that are perhaps even universally valid? Such investigations presuppose that we can identify different instances and stages of language change. Speakers start using linguistic expressions with new meanings, they combine linguistic material in new ways to express new meanings and so on. Researchers of historical phonology have uncovered generally valid laws and generalisations, and many of them are reasonably well understood. In the area of syntax and semantics, the research into patterns of development has also been successful, but in the area of pragmatics the investigations into pathways of change are still very much at the beginning. Before we can hope to be in a position to tackle such problems, a range of more basic problems have to be confronted. We have to be able to establish the meaning potentials of pragmatic units, their categorisation and their context. These and related problems will be briefly outlined in the subsequent sections.

\subsection{Meaning problem (semasiology, form-to-function)}

Older texts pose problems of interpretation. In order to arrive at reliable conclusions, it is necessary to distinguish clearly between the conventionalised meaning potential of a linguistic expression and its actual usage in a particular context (see, for instance, Fritz 2005: 6). It is essential to understand the precise meaning of individual words that are used in the texts under scrutiny, and this requires detailed investigations into how a particular author and his or her contemporaries generally used a word or expression. How would a contemporary audience have understood and interpreted it? This is the semasiological approach in semantics, which investigates the meanings and meaning potentials of specific expressions. Within historical pragmatics, the meaning problem is most explicitly tackled in approaches that have been called "form-to-function" (see above), in which specific linguistic forms are taken as a starting point in order to investigate their pragmatic impact in specific situations.

In historical pragmatics, we deal with the pragmatic effect of utterances and even of entire texts. How, for instance, can the illocutionary force or even the perlocutionary effect of a specific speech act be established? To what extent were spe- 
cific utterances considered to be ironic, polite or insulting? Our modern intuition may often be an unreliable guide in this respect. What comes across as polite may have been understood as ironic by a contemporary audience or vice versa. The interpretation of irony and politeness requires a large amount of contextual knowledge. If a speaker pays a compliment, the addressee needs to have some estimation of the speaker's real opinion in order to be able to interpret the praise as a real compliment, an empty politeness phrase or an ironic slur. With the additional distance of the linguistic analyst, such interpretations become more difficult and more prone to error.

Researchers dealing with the history of politeness or with expressive speech acts have to focus on this problem, and a variety of solutions have been proposed. In an investigation of insults, for instance, Jucker and Taavitsainen (Jucker 2000b; Jucker and Taavitsainen 2000; Taavitsainen and Jucker 2007) suggest a two-fold approach: on the one hand, a careful study of the reaction of the addressee can reveal instances that were considered to be insulting to him or her, and, on the other hand, a study of relevant speech-act verbs in their own context of use may reveal metadiscourse on the speech act under investigation. People who talk about insults may give indications as to how they interpret specific utterances.

\subsection{Identification problem (onomasiology, function-to-form)}

The identification problem is the mirror image of the meaning problem. Researchers who want to investigate specific speech acts, for instance, need to be able to identify expressions of politeness and other speech functions in the texts that they are studying. Very often the identification of a specific speech function is not a trivial matter. In an investigation of insults, for instance, the researcher has to find identification procedures for this particular speech act (Jucker 2000b; Jucker and Taavitsainen 2000). This corresponds to the onomasiological approach in semantics. The researcher starts with a speech function and searches for the different ways in which speakers of a language at a given time realised this function.

Two types of evidence can be adduced in the identification process. First, explicit meta-comments contain discussions of particular speech acts or politeness and tell us a great deal about the cultural practices of the period in question. Through such textual clues, we may be able to locate the linguistic elements that are used for the realisation of particular speech acts. Speakers use labels to refer to specific speech acts, and a semantic analysis of these verbs can give us insights into the speech acts themselves. The usefulness of handbooks, guides to letter writing, language textbooks and various manuals needs to be mentioned in this connection as well.

Second, in fictional dialogues, reported actual dialogues or letters written in response to other letters, we may get direct reactions to specific speech acts, i.e. an indication of the perlocutionary effects. An angry reaction of indignation to a 
preceding utterance may tell us that this utterance was perceived as an insult, for instance. The second parts are, however, fairly seldom available. For instance, in correspondence, letters may have passed through several hands and the survival of ephemeral materials is haphazard. This state of affairs enhances the value of fictional material, and drama is most helpful in this respect as the second turns are often provided.

It is not always easy or even possible to distinguish between the meaning problem and the identification problem. Contextual information in the form of interlocutor reactions can be seen as the link between the linguistic form and what we know about its function. If we use this link to get from the function to the linguistic form, we are dealing with the identification problem. If we go the other way and use it to get from the linguistic form to its function, we are dealing with the meaning problem.

The situation may be even more complex, especially if it is not entirely clear whether we are dealing with a functional or a formal entity. The speech act of thanking is a case in point. On the face of it, it seems that thanking is a clear case of a speech function, but it may in fact be difficult to define it without recourse to the occurrence of elements such as thanks (or alternative expressions with obliged or grateful). It is well known that some speech acts have a limited range or realisational pattern, such as, for instance, apologies, which in English tend to include such standard phrases as pardon, excuse or sorry (see Deutschmann 2003). And, therefore, it may not be entirely clear whether the speech acts of thanking or apologising can be defined independently of their realisational patterns. Furthermore, if an identification procedure has been found for a specific speech act at a given point in the history of English, it still remains an open question whether the same procedure can be used at other points in the history of English. Apologies in Presentday English are regularly realised by words such as pardon, excuse or sorry. But, in earlier stages of English, the range of realisational patterns was much less standardised, and different search patterns have to be established.

\subsection{Categorisation problem}

In addition to the identification of specific meanings, the historical pragmaticist also has to classify and categorise the elements under investigation. To take a clear example, category boundaries have been drawn differently by different scholars for discourse markers and interjections (see the relevant chapters in this volume). Other areas are even more complicated. Studies on modal expressions in English provide evidence of such difficulties in various periods of language history. For instance, Mazzon (2009: 51), who investigates modals in Middle English, includes much more in the category of modal expressions than many other scholars. In Present-day English, ongoing changes with core modals and semi-modals undergoing extensive shifts have been studied, and the categorisation difficulties of English 
modality are obvious. The use of modal auxiliaries is diminishing, and there is a tendency towards monosemy, the prevalence of one meaning over others, with minor and marginal usages of core modals declining more than others. In contrast, there is a substantial rise in the frequency of the use of semi-modals, though the extent to which these two trends are connected is unclear; e.g. must is exceptional in many respects (Leech et al. 2009: 89-90, 116).

Speech acts provide more evidence of the problem. Kohnen (2008) classifies a range of elements as directives in the history of English. He distinguishes four different constructions as directives. The first consists of a matrix clause with a directive speech-act verb and an embedded clause: Ic bidde eow pat ... 'I ask you to ...' (Kohnen 2008: 30). These he calls "directive performatives". The second type consists of the phrase pu scealt or ge sculon 'you shall' followed by an infinitival verb phrase (2008: 33). This construction, however, is used both in directive and in descriptive contexts. The third construction consists of uton followed by an infinitive (2008: 35) and is usually translated as let's. Finally, the fourth construction contains a combination of neodpearf or pearf 'need' plus a first- or a second-person pronoun (2008: 39). For such an analysis it is obviously necessary to determine the precise illocution of individual utterances containing these constructions. As a second analytical step, the utterance is then assigned to the speech-act category of directives. Thus it is not enough to analyse individual utterances; together they provide classes of elements, and several such classes may be combined in a hierarchical way to form larger speech-act inventories, such as one of Searle's (1979: $14,15)$ original speech-act types: directives, commissives, assertives and expressives (or some other classification).

Grzega (2008) shows that such a categorisation may be very difficult. He looks at different forms of greetings in the history of English and finds considerable differences over the centuries. Greetings fluctuate between explicitly formulated wishes or questions and conversational markers. He categorises them on the basis of the motivation for their form. In Old English, attention getters and wishes for good health were frequently used as greetings. In Middle English, enquiries about the addressee's health and wishes for prosperity or well-being took their place. Several issues are at stake here: we have to take cultural differences of directness and indirectness conventions into account and consider the changing conceptions of politeness in language histories. Sincerity, irony and sarcasm provide additional challenges that have to do with speaker attitudes. Further studies are needed to shed new light on the developments.

\subsection{Inventory problem}

The inventory problem is the mirror image of the categorisation problem. While categorisation takes individual instances of a particular utterance type and tries to classify them on the basis of their similarities in form or function, an inventory 
starts with the superordinate category and tries to establish a full inventory of all such categories. The examples given in the previous passage about the categorisation problem can therefore also be viewed from this angle. The categorisation classifies different types of utterances as directives, for instance, and, in the next step of the analysis, an attempt is made to establish a comprehensive inventory of all the different types of directives at a given point in the history of a language, and ultimately to trace the changes in this inventory over time. For this, it is necessary to establish the sociohistorical context in which the changes take place in order to gain knowledge of larger pragmatic patterns of change.

Such a research programme assesses how the proportions of items in a particular field change and lead to large-scale language change. A new inventory of modal expressions, for instance, seems to be in order as core modals undergo extensive changes and alternative expressions gain ground (Leech at al. 2009: 268-269). Greetings, mentioned in the previous section, provide a pertinent example at the utterance level. Inventories for different periods of English have been outlined by Grzega (2008), and there is a comparative study of greetings from the early days of philology in Old English, Old High German and Old Norse (Stroebe 1911).

In some cases, it is difficult to distinguish between the categorisation problem and the inventory problem. If a researcher tries to give a comprehensive account of all elements of a particular category, this is both an instance of the categorisation problem (to what extent are the elements instances of this category?) and of the inventory problem (what is the inventory of all the elements that belong to this category?).

\subsection{Contextualisation problem}

Context provides a multilayered analytical grid to historical pragmatics, and various models have been presented to describe the scale from macro- to micro-context and their analyses (see Culpeper, this volume). The context of culture provides one end of the scale. This has been taken into account e.g. by positing the various periods of language history as different cultural stages and by applying the methods of cross-cultural comparisons to these studies (see Culpeper and Archer 2008). The sociohistorical context of text production is also a macro-level issue. An intermediate level is provided by the genres of writing as they are important in guiding language activities, both the production of texts and their reception, and in this way investigations into genre distinctions also contextualise pragmatic elements. Speech acts, for example, are comprehensible only within their contexts, as meanings may easily be reversed and the only way to interpret them is through the context of utterance. When we analyse insults in a play, for instance, we place a speech act within its larger linguistic context. Micro-level analyses are at the other end of the scale, with the local level of text in focus. Pronoun references and meanings of deictic features in individual texts, for instance, would count in this category. More 
general questions essential to historical pragmatics are e.g. the following: What is the social context in which a particular element is being used? Who uses it in which genre/communicative context?

\section{The structure of the present volume}

As pointed out above (section 3), the present volume adopts the broader sociologically-based Continental European approach to historical pragmatics, but it also includes important contributions within the narrower Anglo-American approach. The overall design conveys the notion of pragmatics as being a perspective rather than an additional component of language theory. The contents of the contributions range from micro- to macro-analyses of language use. English data prevails in many chapters; in fact, the entire volume is biased towards research on English historical pragmatics, although in some areas other languages take the leading role, e.g. in studies on controversies and on rituals. But, in general, there is far more relevant research on English than on any other language and we did not try to redress the balance by artificially foregrounding work on non-English languages. It is to be hoped that in due course work on other languages will expand and enrich the overall picture of historical pragmatics in significant ways.

The volume is divided into six sections. The first section is devoted to data problems and methodology and consists of two chapters. The first chapter, by Merja Kytö, deals with data in historical pragmatics and also discusses some of the methodological issues in corpus linguistics - the use of corpora being a prevailing trend at least in English historical pragmatics. Jonathan Culpeper's chapter deals with historical sociopragmatics. The point of departure is the fundamental issue of what we understand by pragmatics and whether a separate field of sociopragmatics is needed, but the chapter also answers some pertinent methodological questions and serves as a good introduction to the issues discussed in other sections of the volume.

The second section is entitled "Diachrony" and contains papers that belong to the Anglo-American tradition of historical pragmatics. They are mostly concerned with the pragmatic causes of language change, and illuminate the problems and central issues from several angles. The first three deal with core processes of language change: grammaticalisation, subjectification and intersubjectification, and pragmaticalisation and discursisation. Some of these processes have strong semantic associations or at least shades of semantic colouring, but they have pragmatic motivations and can also be viewed from the angle of historical pragmatics, as is done in this volume. Elizabeth Closs Traugott's chapter takes us more clearly to the area of historical semantics, viewed from the angle of pragmatic change. Traugott's study demonstrates how interfaces often yield new insights. María José López-Couso reviews the literature on subjectification and intersubjectification, 
while Claudia Claridge and Leslie Arnovick provide an overview and four case studies on pragmaticalisation and - as a special case of pragmaticalisation - discursisation. Finally, Brigitte Nerlich's contribution is devoted to metaphor and metonymy and their function in language change.

The third section is devoted to two authors of fiction. Mari Pakkala-Weckström reviews the extensive historical pragmatic work on Geoffrey Chaucer, and Beatrix Busse and Ulrich Busse on William Shakespeare. There is more work from a historical pragmatic perspective on these two authors than on any other single author. Some occasional historical pragmatic work has been carried out on fiction in Medieval French (e.g. Lebsanft 1988, 1999) and in Middle High German (e.g. Weigand 1988). It is hoped that this section serves as inspiration for more, as there is great potential in these unexplored areas. These chapters will be particularly useful for researchers seeking an overview of historical pragmatic work that has been carried out on the writings of Chaucer and Shakespeare, but they will be of interest to others as well because there are areas of overlap between these chapters and other sections (e.g. on discourse markers or on address terms).

The fourth section is devoted to the pragmatic analyses of short expressions: discourse markers, interjections and expletives, and address terms. This subfield of historical pragmatics is well established with a large number of studies from the 1980s and 1990s, and other languages besides English are also represented. Laurel Brinton's contribution deals with discourse markers, including those in French, and Elke Gehweiler's with interjections and expletives, including in German and Swiss German among others. Gabriella Mazzon's chapter is devoted to address terms and also cites relevant examples from a large range of languages.

The section on interactional pragmatics deals with speech acts, politeness, controversies and rituals, and includes chapters by Dawn Archer, Minna Nevala, Gerd Fritz and Marcel Bax. They all deal with the dimension of self-other in various attestations. Researchers on speech acts have been active in recent years and methodologies are being developed to overcome the difficulties of locating relevant material. Politeness is another research-intensive area with more ambitious goals for politeness studies than earlier, as the long diachrony of language histories and the reverse side of impoliteness are also addressed. Controversies make a welcome exception to the domination of English studies, as work on the German language is leading in this field, with religious controversies of the Reformation period playing an important role. Studies on rituals have mainly been conducted within anthropology, but more recently also in historical pragmatics, with Dutch studies in a foregrounded position.

The final section is devoted to discourse domains. The chapters deal with religious discourse (by Thomas Kohnen), scientific discourse (by Päivi Pahta and Irma Taavitsainen), news discourse (by Claudia Claridge), courtroom discourse (by Kathleen Doty), correspondence (by Minna Palander-Collin) and literary discourse (by Susan Fitzmaurice). Discourse domains characterise the source of the data ana- 
lysed in these chapters, and a certain amount of overlap is unavoidable with e.g. the pragmatic analysis of short expressions and interactional pragmatics. The overall angle is, however, different. The extent to which such elements have received attention in particular discourse domains varies, and the descriptions of the work done to date provide readers with state-of-the-art accounts of recent trends, ongoing work and indications of desiderata for future studies.

\section{Conclusions}

This volume is an attempt to describe the position of historical pragmatics in the large field of pragmatics, and one of the goals is to relate historical pragmatics to the field of historical linguistics; this is in accordance with the notion that historical pragmatics is situated at the crossroads of the two disciplines - pragmatics and historical linguistics (as formulated in the blurb of the Journal of Historical Pragmatics 2000). The field was launched as a systematic area of research in 1995, though there had been some sporadic early studies already in the 1980s. During its lifetime, we have seen a move towards more ambitious research goals and more interdisciplinary work. The area has grown considerably with the widening of the field of pragmatics to an overarching perspective on any aspect of language use in communication at any level of structure (Verschueren 1987: 5). More recently, the definition has broadened to include general cognitive, social and cultural perspectives (Verschueren 1999: 7). At the same time in pragmatics as in other fields of linguistics, the view that the present cannot be understood without knowledge of the past has gained ground, and historical pragmatics has grown from a sidetrack to an area in its own right. It has also become more common to refer to past stages to give depth to present-day language developments (see Traugott above). Like pragmatics, historical pragmatics has become a perspective of language use rather than being at a crossroads, where it was located ten years ago (see e.g. the chapters on language domains).

As the volume shows, exciting new areas of research can grow out of such a perspective. Cross-fertilisation of research approaches and methodologies are fruitful in inspiring new explorations that lead to innovative insights and open up new research paradigms. The contributions in this volume make use of several other fields of research that serve as launching pads for new thoughts: psychology, cognitive sciences, sociology, anthropology, cultural history and medical history or history of science are mentioned in various contributions. One of our bold statements was to aim at providing a roadmap for interdisciplinary cooperation. We hope that these surveys will fulfil their function and provide incentive for new extensions to - as yet - unknown areas.

In addition, several new directions have been indicated as desiderata for future studies. The availability of new materials also opens up new avenues for studies. For example, new authentic data are more readily available in electronic resources 
that only a few years ago were buried in repositories of libraries in different continents; now the resources are available from scholars' laptops on their own desks. New data lead to new methods, and these are being developed for historical pragmatics, e.g. in corpus linguistics and multimodal analysis. Corpus-linguistic analyses can be carried out more efficiently and reliably with new software, and pragmatic applications of corpus methods have recently become a focus of attention, e.g. in speech-act studies, so much so that the label "corpus pragmatics" has been carried over into more common use (see e.g. Jucker, Schreier and Hundt 2009).

The future of the discipline looks bright. A great deal has already been completed and guidelines are set for future directions, but there is a great deal that we do not know yet, and there are unexplored areas and possibilities for new discoveries. We hope that the chapters in this volume will serve as inspiration for the future.

\section{Acknowledgements}

We are grateful to Wolfram Bublitz for bringing additional points on present trends in pragmatics to our attention, and to Turo Hiltunen and Daniela Landert for their pertinent comments on a draft version of this introduction.

\section{Electronic sources}

EEBO (Early English Books Online) http://eebo.chadwyck.com/home.

ECCO (Eighteenth Century Collections Online, Parts 1 and 2)

http://www.jisc-collections.ac.uk/ecco.

HTE (Historical Thesaurus of English) http://www.arts.gla.ac.uk/sesl1/EngLang/thesaur/.

OED (Oxford English Dictionary) http://oed.com/.

\section{References}

Arnovick, Leslie K.

1999 Diachronic Pragmatics. Seven Case Studies in English Illocutionary Development. (Pragmatics \& Beyond New Series 68.) Amsterdam/Philadelphia: John Benjamins.

Borgmeier, Raimund, Herbert Grabes and Andreas H. Jucker (eds.)

1998 Anglistentag 1997 Giessen: Proceedings. Trier: Wissenschaftlicher Verlag Trier.

Brinton, Laurel J.

1996 Pragmatic Markers in English. Grammaticalization and Discourse Functions. Berlin/New York: Mouton de Gruyter.

Brinton, Laurel J.

1998 'The flowers are lovely; only, they have no scent': The evolution of a pragmatic marker in English. In: Raimund Borgmeier, Herbert Grabes and Andreas H. Jucker (eds.), 9-33. 
Brinton, Laurel J.

2001 Historical discourse analysis. In: Deborah Schiffrin, Deborah Tannen and Heidi E. Hamilton (eds.), The Handbook of Discourse Analysis, 138-160. Oxford: Blackwell.

Brinton, Laurel J.

2006 Pathways in the development of pragmatic markers in English. In: Ans van Kemenade and Bettelou Los (eds.), 307-334.

Brinton, Laurel J.

2008 The Comment Clause in English. Syntactic Origins and Pragmatic Developments. Cambridge: Cambridge University Press.

Brown, Roger, and Albert Gilman

1960 The pronouns of power and solidarity. In: Thomas A. Sebeok (ed.), Style in Language, 253-276. Cambridge, MA.: MIT Press.

Brown, Roger, and Albert Gilman

1989 Politeness theory and Shakespeare's four major tragedies. Language in Society 18.2: 159-212.

Culpeper, Jonathan

2010 Historical pragmatics. In: Louise Cummings (ed.), The Pragmatics Encyclopedia, 188-192. London/New York: Routledge.

Culpeper, Jonathan, and Dawn Archer

2008 Requests and directness in Early Modern English trial proceedings and play texts, 1640-1760. In: Andreas H. Jucker and Irma Taavitsainen (eds.), 45-84.

Culpeper, Jonathan, and Merja Kytö

1999 Modifying pragmatic force: Hedges in a corpus of Early Modern English dialogues. In: Andreas H. Jucker, Gerd Fritz and Franz Lebsanft (eds.), 293-312.

Culpeper, Jonathan, and Merja Kytö

2000 Data in historical pragmatics: Spoken discourse (re)cast as writing. Journal of Historical Pragmatics 1.2: 175-199.

Culpeper, Jonathan, and Merja Kytö

2006 'Good, good indeed, the best that ere I heard': Exploring lexical repetitions in the Corpus of English Dialogues 1560-1760. In: Irma Taavitsainen, Juhani Härmä and Jarmo Korhonen (eds.), Dialogic Language Use. Dimensions du dialogisme. Dialogischer Sprachgebrauch, 69-85. (Mémoires de la Société Néophilologique de Helsinki 66.) Helsinki: Société Néophilologique.

Culpeper, Jonathan, and Merja Kytö

2010 Early Modern English Dialogues. Spoken Interaction as Writing. Cambridge: Cambridge University Press.

Deutschmann, Mats

2003 Apologising in British English. (Skrifter från moderna språk 10.) Umeå: Institutionen för moderna språk, Umeå University.

Ernst, Gerhard, Martin-Dietrich Gleßgen, Christian Schmitt and Wolfgang Schweickard (eds.)

2006 Romanische Sprachgeschichte. Ein internationales Handbuch zur Geschichte der romanischen Sprachen. Volume 2. (Handbooks of Linguistics and Communication Science, HSK 23.1.-3.) 20 Berlin/New York: Walter de Gruyter.

Fitzmaurice, Susan M., and Irma Taavitsainen (eds.)

2007 Methods in Historical Pragmatics. (Topics in English Linguistics 52.) Berlin/ New York: Mouton de Gruyter. 
Fries, Udo

1998 Dialogue in instructional texts. In: Raimund Borgmeier, Herbert Grabes and Andreas H. Jucker (eds.), 85-96.

Fritz, Gerd

1994 Geschichte von Dialogformen. In: Gerd Fritz and Franz Hundsnurscher (eds.), Handbuch der Dialoganalyse, 545-562. Tübingen: Max Niemeyer.

Fritz, Gerd

1995 Topics in the history of dialogue forms. In: Andreas H. Jucker (ed.), 469-498.

Fritz, Gerd

1997 Remarks on the history of dialogue forms. In: Etienne Pietri (ed.), Dialoganalyse V. Referate der 5. Arbeitstagung. Paris 1994, 47-55. (Beiträge zur Dialogforschung 15.) Tübingen: Max Niemeyer.

Fritz, Gerd

2005 Einführung in die historische Semantik. (Germanistische Arbeitshefte 42.) Tübingen: Max Niemeyer.

Grzega, Joachim

2008 Hāl, Hail, Hello, Hi: Greetings in English language history. In: Andreas H. Jucker and Irma Taavitsainen (eds.), 165-193.

Held, Gudrun

2006 Schwerpunkte der historischen Pragmalinguistik: exemplarische Fallstudien. In: Gerhard Ernst, Martin-Dietrich Gleßgen, Christian Schmitt and Wolfgang Schweickard (eds.), 2,302-2,318.

Honkapohja, Alpo, Samuli Kaislaniemi and Ville Marttila

2009 Digital editions for corpus linguistics: Representing manuscript reality in electronic corpora. In: Andreas H. Jucker, Daniel Schreier and Marianne Hundt (eds.), 451-475.

Horn, Laurence R., and Gregory Ward (eds.)

2004 The Handbook of Pragmatics. Oxford: Blackwell.

Huang, Yan

2007 Pragmatics. Oxford: Oxford University Press.

Jacobs, Andreas, and Andreas H. Jucker

1995 The historical perspective in pragmatics. In: Andreas H. Jucker (ed.), 3-33. Jucker, Andreas H. (ed.)

1995 Historical Pragmatics. Pragmatic Developments in the History of English. (Pragmatics \& Beyond New Series 35.) Amsterdam/Philadelphia: John Benjamins.

Jucker, Andreas H.

2000a English historical pragmatics: Problems of data and methodology. In: Gabriella di Martino and Maria Lima (eds.), English Diachronic Pragmatics, 17-55. Napoli: CUEN.

Jucker, Andreas H.

2000b Slanders, slurs and insults on the road to Canterbury. Forms of verbal aggression in Chaucer's Canterbury Tales. In: Irma Taavitsainen, Terttu Nevalainen, Päivi Pahta and Matti Rissanen (eds.), Placing Middle English in Context, 369-389. (Topics in English Linguistics 35.) Berlin/New York: Mouton de Gruyter. 
Jucker, Andreas H.

2006 Historical pragmatics. In: Jan-Ola Östman and Jef Verschueren in collaboration with Eline Versluys (eds.), Handbook of Pragmatics 2006, 1-14. Amsterdam/Philadelphia: John Benjamins.

Jucker, Andreas $\mathrm{H}$.

2008 Historical pragmatics. Language and Linguistics Compass 2.5: 894-906.

Jucker, Andreas H., Gerd Fritz and Franz Lebsanft

1999a Historical dialogue analysis: Roots and traditions in the study of the Romance languages, German and English. In: Andreas H. Jucker, Gerd Fritz and Franz Lebsanft (eds.), 1-33.

Jucker, Andreas H., Gerd Fritz and Franz Lebsanft (eds.)

1999b Historical Dialogue Analysis. Amsterdam/Philadelphia: John Benjamins.

Jucker, Andreas H., Gerold Schneider, Irma Taavitsainen and Barb Breustedt

2008 Fishing for compliments: Precision and recall in corpus-linguistic compliment research. In: Andreas H. Jucker and Irma Taavitsainen (eds.), 273-294.

Jucker, Andreas H., Daniel Schreier and Marianne Hundt (eds.)

2009 Corpora: Pragmatics and Discourse. Papers from the 29th International Conference on English Language Research on Computerized Corpora (ICAME 29). Ascona, Switzerland, 14-18 May 2008. (Language and Computers: Studies in Practical Linguistics 68.) Amsterdam: Rodopi.

Jucker, Andreas H., and Irma Taavitsainen

2000 Diachronic speech act analysis: Insults from flyting to flaming. Journal of Historical Pragmatics 1.1: 67-95.

Jucker, Andreas H., and Irma Taavitsainen

2008a Apologies in the history of English: Routinized and lexicalized expressions of responsibility and regret. In: Andreas H. Jucker and Irma Taavitsainen (eds.), 229-244.

Jucker, Andreas H., and Irma Taavitsainen (eds.)

2008b Speech Acts in the History of English. (Pragmatics \& Beyond New Series 176.)

Amsterdam/Philadelphia: John Benjamins.

Jucker, Andreas H., and Irma Taavitsainen.

Forthcoming Pragmatic variables. In: J. M. Hernández-Campoy (ed.) The Handbook of Historical Sociolinguistics, Oxford: Wiley-Blackwell.

Koch, Peter

1999 Court records and cartoons: Reflections of spontaneous dialogue in Early Romance texts. In: Andreas H. Jucker, Gerd Fritz and Franz Lebsanft (eds.), 399-429.

Koch, Peter, and Wulf Oesterreicher

1985 Sprache der Nähe - Sprache der Distanz: Mündlichkeit und Schriftlichkeit im Spannungsfeld von Sprachtheorie und Sprachgeschichte. Romanistisches Jahrbuch 36: 15-43.

Kohnen, Thomas

2008 Directives in Old English: Beyond politeness? In: Andreas H. Jucker and Irma Taavitsainen (eds.), 27-44.

Labov, William

1994 Principles of Linguistic Change. Vol. I: Internal Factors. Oxford: Blackwell. 
Lebsanft, Franz

1988 Studien zu einer Linguistik des Grusses. Sprache und Funktion der altfranzö-

Lebsanft, Franz sischen Grußformeln. Tübingen: Max Niemeyer.

1999 A Late Medieval French bargain dialogue (Pathelin II), Or: Further remarks on the history of dialogue forms. In: Andreas H. Jucker, Gerd Fritz and Franz Lebsanft (eds.), 269-292.

Leech, Geoffrey, Marianne Hundt, Christian Mair and Nicholas Smith

2009 Change in Contemporary English. A Grammatical Study. (Studies in English Language.) Cambridge: Cambridge University Press.

Lötscher, Andreas

1981 Zur Sprachgeschichte des Fluchens und Beschimpfens im Schweizerdeutschen. Zeitschrift für Dialektologie und Linguistik 48: 145-160.

Mazzon, Gabriella

2003 Pronouns and nominal address in Shakespearean English: A socio-affective marking system in transition. In: Irma Taavitsainen and Andreas H. Jucker (eds.), 223-249.

Mazzon, Gabriella

2009 Interactive Dialogue Sequences in Middle English Drama. (Pragmatics \&

Milroy, James Beyond New Series 185.) Amsterdam/Philadelphia: John Benjamins.

1992 Linguistic Variation and Change: On the Historical Sociolinguistics of English. (Language in Society 19.) Oxford: Blackwell.

Nevalainen, Terttu, and Helena Raumolin-Brunberg

1995 Constraints on politeness: The pragmatics of address formulae in Early English correspondence. In: Andreas H. Jucker (ed.), 541-601.

Nevalainen, Terttu, and Helena Raumolin-Brunberg

2003 Historical Sociolinguistics: Language Change in Tudor and Stuart England. London: Pearson Education.

Radtke, Edgar

2006 Historische Pragmalinguistik: Aufgabenbereiche. In: Gerhard Ernst, MartinDietrich Gleßgen, Christian Schmitt and Wolfgang Schweickard (eds.), 2,292-2,302.

Rissanen, Matti

1986 Variation and the study of English historical syntax. In: David Sankoff (ed.), Diversity and Diachrony, 97-109. Amsterdam/Philadelphia: John Benjamins.

Salmon, Vivian

1965 Sentence structures in colloquial Shakespearian English. Transactions of the

Searle, John R. Philological Society 64: 105-140.

1979 Expression and Meaning. Studies in the Theory of Speech Acts. Cambridge:

Sell, Roger D. Cambridge University Press.

1985 Politeness in Chaucer: Suggestions towards a methodology for pragmatic stylistics. Studia Neophilologica 57: 175-185.

Sell, Roger D.

1991 The politeness of literary texts. In: Roger D. Sell (ed.), Literary Pragmatics, 208-224. London/New York: Routledge. 
Sell, Roger D.

2000 Literature as Communication. (Pragmatics \& Beyond New Series 78.) Amsterdam/Philadelphia: John Benjamins.

Sell, Roger D.

2001 Historical but non-determinist pragmatics of literary communication. Journal of Historical Pragmatics 2.1: 1-32.

Seoane, Elena

2006 Information structure and word order change: The passive as an informationrearranging strategy in the history of English. In: Ans van Kemenade and Bettelou Los (eds.), 360-391.

Stroebe, Klara

1911 Altgermanische Grussformen. Heidelberg: Winter.

Taavitsainen, Irma

1995 Interjections in Early Modern English: From imitation of spoken to conventions of written language. In: Andreas H. Jucker (ed.), 439-465.

Taavitsainen, Irma

Forthcoming Historical pragmatics. In: Laurel J. Brinton and Alexander Bergs (eds.), Handbook of Historical Linguistics of English. (Handbooks of Linguistics and Communication Science, HSK.) Berlin/New York: Mouton de Gruyter.

Taavitsainen, Irma, and Susan M. Fitzmaurice

2007 Historical pragmatics: What it is and how to do it. In: Susan M. Fitzmaurice and Irma Taavitsainen (eds.), 11-36.

Taavitsainen, Irma, and Andreas H. Jucker (eds.)

2003 Diachronic Perspectives on Address Term Systems. (Pragmatics \& Beyond New Series 107.) Amsterdam/Philadelphia: John Benjamins.

Taavitsainen, Irma, and Andreas H. Jucker

2007 Speech act verbs and speech acts in the history of English. In: Susan M. Fitzmaurice and Irma Taavitsainen (eds.), 107-138.

Taavitsainen, Irma, and Andreas H. Jucker

2008 'Methinks you seem more beautiful than ever': Compliments and gender in the history of English. In: Andreas H. Jucker and Irma Taavitsainen (eds.), $195-228$.

Traugott, Elizabeth Closs

2004 Historical pragmatics. In: Laurence R. Horn and Gregory Ward (eds.), 538-561.

Traugott, Elizabeth Closs

2006 The semantic development of scalar focus modifiers. In: Ans van Kemenade and Bettelou Los (eds.), 335-359.

Traugott, Elizabeth Closs

2008 The state of English language studies: A linguistic perspective. In: Marianne Thormählen (ed.), English Now. Selected Papers from the 20th IAUPE Conference in Lund 2007, 199-225. Lund: Lund Studies in English.

Traugott, Elizabeth Closs, and Richard B. Dasher

2005 Regularity in Semantic Change. Cambridge: Cambridge University Press.

Valkonen, Petteri

2008 Showing a little promise: Identifying and retrieving explicit illocutionary acts from a corpus of written prose. In: Andreas H. Jucker and Irma Taavitsainen (eds.), 247-272. 
van Kemenade, Ans, and Bettelou Los (eds.)

2006 The Handbook of The History of English. Oxford: Blackwell.

Verschueren, Jef

1987 The pragmatic perspective. In: Marcella Bertuccelli-Papi and Jef Verschueren (eds.), The Pragmatic Perspective: Selected Papers from the 1985 International Pragmatics Conference, 3-8. (Pragmatics \& Beyond Companion Series 5.) Amsterdam/Philadelphia: John Benjamins.

Verschueren, Jef

1999 Understanding Pragmatics. (Understanding Language Series.) London: Arnold.

Verschueren, Jef, Jan-Ola Östman, Jan Blommaert and Chris Bulcaen (eds.)

2003 Handbook of Pragmatics. Amsterdam/Philadelphia: John Benjamins.

Weigand, Edda

1988 Historische Sprachpragmatik am Beispiel: Gesprächsstrukturen im Nibelungenlied. Zeitschrift für deutsches Altertum und deutsche Literatur 117: 159-173.

Weinreich, Uriel, William Labov and Marvin Herzog

1968 Empirical foundations for a theory of language change. In: Winfred P. Lehmann and Yakov Malkiel (eds.), Directions for Historical Linguistics: A Symposium, 95-188. Austin: University of Texas Press. 


\section{Data and methodology}


Bereitgestellt von | UZH Hauptbibliothek / Zentralbibliothek Zürich 